\title{
PELATIHAN REACHING OBLIQUE CRUNCH LEBIH MENINGKATKAN KEKUATAN OTOT PERUT DARI PADA PELATIHAN PILATE TOE TAPS PADA SISWA PUTRA PESERTA EKSTRAKURIKULER PENCAK SILAT SMP NEGERI 2 KUTA
}

\author{
Md Ayu Puspita Citra Novelia ${ }^{1}$, Susy Purnawati ${ }^{2}$, Luh Made Indah Sri Handari Adiputra ${ }^{2}$, \\ Ketut Tirtayasa $^{2}$, I Putu Adiartha Griadhi², I Dewa Ayu Inten Dwi Primayanti². \\ ${ }^{1}$ Program Magister Fisiologi Keolahragaan, Fakultas Kedokteran, Universitas Udayana, Denpasar \\ ${ }^{2}$ Departemen Ilmu Faal, Fakultas Kedokteran, Universitas Udayana, Denpasar.
}

e-mail: citranovelia075@gmail.com

\begin{abstract}
ABSTRAK
Dalam pertandingan pencak silat otot perut sangat dilindungi oleh atlet pencak silat, karena perut merupakan daerah seorang atlet pencak silat mencari point serang sehingga atlet pencak silat memerlukan kekuatan otot perut yang baik untuk menunjang serangan dari lawan. Latihan $R O C$ dan PTT merupakan latihan untuk meningkatkan kekuatan otot perut. Penelitian ini bertujuan untuk membuktikan pelatihan ROC lebih efektif dari pelatihan PTT dalam meningkatkan kekuatan otot perut pada atlet putra peserta ekstrakurikuler pencak silat SMP Negeri 2 Kuta. Jenis penelitian true eksperimental dengan rancangan randomized pre-test and post-test with control groups design. Subjek penelitian adalah siswa putra peserta ekstrakulikuler pencak silat SMP Negeri 2 Kuta yang berjumlah 32 orang dan dibagi dalam dua kelompok. Kelompok 1 diberikan pelatihan $R O C$ dan Kelompok 2 diberi pelatihan $P T T$, frekuensi latihan 3 kali seminggu selama 6 minggu. Pengukuran kekuatan otot perut dapat diukur menggunakan test situp selama 30 detik. Hasil penelitian pada ke dua kelompok didapatkan rerata kekuatan otot perut sebelum pelatihan $R O C 19,1 \pm 3,7$ per 30 detik, sedangkan sesudah pelatihan menjadi $24,9 \pm 4,4$ per 30 detik. Rerata kekuatan otot perut sebelum pelatihan $P T T 18,1 \pm 3,2$ per 30 detik, sedangkan sesudah pelatihan $P T T$ menjadi 20,3 $\pm 3,5$ per 30 detik. Uji beda rerata kekuatan otot perut antara Kelompok 1 dan Kelompok 2 dengan menggunakan independent $t$-test menunjukan bahwa $\mathrm{p}=0,00(\mathrm{p}<0,05)$. Dapat disimpulkan bahwa intervensi pada Kelompok 1 maupun Kelompok 2 memberikan efek kekuatan otot perut yang signifikan dimana intervensi $R O C$ lebih meningkatkan kekuatan otot perut atlet putra peserta ekstrakurikuler pencak silat SMP Negeri 2 Kuta. Saran pada penelitian ini diharapkan para pelatih dapat memberikan pelatihan dengan tepat dan menggunakan metode monitoring evaluasi untuk meningkatkan pencapaian prestasi atlet.
\end{abstract}

Kata Kunci: Reaching Oblique Crunch, Pilate Toe Taps, Kekuatan Otot Perut, Pencak Silat 


\title{
REACHING OBLIQUE CRUNCH TRAINING MORE IMPROVING THE STRENGTH OF STOMACH MUSCLE THAN PILATE TOE TAPS TRAINING OF MALE STUDENTS IN EXTRACURRICULAR PENCAK SILAT AT SMPN 2 KUTA
}

\begin{abstract}
In the pencak silat competition, pencak silat athletes should be protected their abdominal muscles, because the abdomen is an area for attacking points so that martial arts athletes need good abdominal muscle strength to support the attacks of the opponent. ROC and PTT exercises are exercises to increase the strength of the abdominal muscles. The purpose of this study is to prove that ROC training is more effective than PTT training in increasing abdominal muscle strength of male athletes in extracurricular pencak silat at SMP Negeri 2 Kuta. This type of true experimental research with randomized pre-test and post-test with control groups design. The subjects of the study were 32 male students in extracurricular pencak silat at SMP Negeri 2 Kuta and were divided into two groups. Group 1 was given ROC training and Group 2 was given PTT training, frequency of the exercise 3 times a week for 6 weeks. Measurement of abdominal muscle strength can be measured using a sit-up test for 30 seconds. The results of the study in both groups obtained the mean abdominal muscle strength before ROC training $19.1 \pm 3.7$ per 30 seconds, whereas after training $24.9 \pm 4.4$ per 30 seconds. The mean abdominal muscle strength before PTT training was $18.1 \pm 3.2$ per 30 seconds, whereas after PTT training it became $20.3 \pm 3.5$ per 30 seconds. Average different test for abdominal muscle strength in group 1 and group 2 using independent t-test showed that $\mathrm{p}=0.00$ ( $\mathrm{p}<0.05$ ). It can be concluded that the interventions in group 1 and group 2 are equally good in providing a significant effect on abdominal muscle strength which the ROC intervention further increases the abdominal strength of male athletes in extracurricular of pencak silat at SMP Negeri 2 Kuta. The suggestion in this research is that the trainers are expected to provide training correctly and use evaluation monitoring methods to improve athlete achievement.
\end{abstract}

Keyword: Reaching Oblique Crunch, Pilate Toe Taps, Abdominal Muscle strenght, Pencak silat.

\section{PENDAHULUAN}

Olahraga pencak silat adalah sebuah cabang olahraga yang asli dari Indonesia, olahraga ini terkenal hingga mancanegara sehingga sangat baik untuk dijadikan ajang meraih prestasi yang terbaik. ${ }^{1}$ Pada pertandingan pencak silat perut sangat dilindungi karena perut termasuk daerah dalam mencari point serang, sehingga dapat dikatakan dalam pencak silat dibutuhkan kekuatan otot perut yang baik ketika menahan serangan dari lawan baik serangan melalui pukulan keras maupun tendangan keras, maka atlet pencak silat memerlukan kekuatan otot perut yang maksimal. $^{2}$

Kekuatan otot merupakan kualiatas yang dibutuhkan dalam pengembangan serta tegangan otot dalam berkontraksi yang maksimal, hal ini diartikan kemampuan dalam mempergunakan gaya ketika melawan hambatan atau beban, kekuatan ini dipengaruhi oleh kualitas kontrol dan volume otot yang bersangkutan. ${ }^{3}$ Kekuatan otot termasuk komponen fisik yang begitu penting terhadap kondisi fisik keseluruhan. Untuk melakukan pelatihan kekuatan secara dinamis ada tiga ketentuan ada empat prinsip yang mendasari antara lain 1) pemberian beban yang berlebih; 2) dilakukan secara pelatihan di susun secara cermat: 3) dilakukan secara progresif selama durasi pelatihan: dan 4) spesifikasi sesuai dengan cabang olaharaga 4 . Pada kehidupan sehari - hari beberapa otot saling berhubungan dengan fungsi mempertahankan organ dalam, aktifitas fungsional seperti berjalan duduk, melompat, kemudian menjaga postur tubuh, serta sebagai 
bentuk gerak. ${ }^{5}$ Kekuatan otot perut merupakan kemampuan dari otot skeletal dalam berkontraksi secara maksimal ketika menerima beban pada saat melakukan aktifitas,

Kekuatan otot merupakan suatu komponen biomotorik yang sering digunakan serta dibutuhkan oleh para atlet berdasarkan kadar kebutuhan yang berbeda-beda antara satu dengan yang lain. Komponen ini mampu ditingkatkan dengan cara pemberian tahanan internal maupun eksternal pada otot. ${ }^{4}$

Berdasarkan pengamatan dilapangan atlet pencak silat SMP Negeri 2 Kuta didapatkan hasil otot perut siswa masih dibawah rata-rata sedangkan untuk menjadi atlet pencak silat memerlukan kekuatan otot perut yang baik. Setiap pertandingan pencak silat atlet akan selalu mencari areal perut, karena perut merupakan area dimana paling mudah mendapat point tendangan, sehingga atlet harus sigap ketika kemungkinan terkena tendangan pada area perut. $^{2}$

Beberapa latihan dalam meningkatkan kekuatan otot perut antara lain pelatihan Reaching oblique crunch merupakan latihan meraih miring dan menyilang yaitu gerakan meraih miring secara menyilang, latihan ini adalah untuk meningkatkan kekuatan otot perut melalui gerakan yang cukup sederhana, gerakan tersebut dimulai pada posisi awal tidur terlentang kedua tangan berada disebelah kiri kanan telinga dan kedua kaki ditekuk kurang lebih 45 derajat, mengangkat batang tubuh dengan tangan lain lurus dan berusaha menyentuh kaki, sedangkan tangan lainnya tetap berada disamping kepala, ketika tangan kiri menyentuh kaki kanan maka hal sebaliknya tangan kanan menyentuh kaki kiri. ${ }^{6}$

Bentuk pelatihan lain yang dapat meningkatkan kekuatan otot perut adalah pelatihan Pilate toe taps merupakan pelatihan mengangkat jari - jari kaki untuk meningkatkan kekuatan otot perut dengan gerakan awal posisi tidur terlentang kemudian kedua tangan berada disamping perut setelah kaki ditekuk sekitar 45 derajat kemudian angkat kedua paha sampai mendekati perut, sedangkan lutut tetap ditekuk usahakan kaki jangan menyentuh lantai agar gerakan lebih efektif. ${ }^{6}$

Pelatihan ini bertujuan meningkatkan kekuatan dari otot perut agar dapat mengurangi lemak pada daerah perut. Latihan akan tercapai jika sesuai dengan tujuan yang kita inginkan serta terprogram secara baik. Program dari pelatihan tersebut akan mencangkup mengenai segala hal tentang intensitas latihan, waktu latihan, frekuensi latihan dan tipe latihan. Program latihan di susun secara sistematik, disesuaikan berdasarkan tujuan dari latihan yang dibutuhkan, serta terukur. Dengan rutinnya latihan dan dilakukan secara berkelanjutan maka akan mendapat hasil yang maksimal. ${ }^{7}$

\section{HIPOTESIS PENELITIAN}

1) Pelatihan Reaching Oblique Crunch meningkatkan kekuatan otot perut siswa putra peserta ekstrakurikuler pencak silat SMP Negeri 2 Kuta.

2) Pelatihan Pilate Toe Taps meningkatkan kekuatan otot perut siswa putra peserta ekstrakurikuler pencak silat SMP Negeri 2 Kuta.

3) Pelatihan Reaching Oblique Crunch lebih meningkatkan kekuatan otot perut dari pada pelatihan Pilate Toe Taps terhadap siswa putra ektrakurikuler pencak silat SMP Negeri 2 Kuta.

\section{METODE PENELITIAN}

Penelitian dilaksanakan di lapangan SMP Negeri 2 Kuta. Untuk pelaksanaan dari latihan reaching oblique crunch dilaksanakan dari pukul 15.00-16.00 Wita sedangkan pelatihan pilate toe taps dilaksanakan dari pukul 16.00-17.00 Wita. Pengumpulan data serta waktu pada penelitian ini dilaksanakan mulai tanggal 1 Desember 2019 s/d 11 Januari 2020. Rancangan pada penelitian ini menggunakan true experimental dengan randomized pre test and post test control group design ${ }^{8}$.

\section{A. Sampel dan Populasi}

Kriteria sampel pada penelitian ini diperoleh dari populasi yang sesuai dengan kriteria eksklusi dan inklusi, sedangkan besar dari sampel ditentukan dari hasil penelitian terdahulu yang dihitung melalui rumus pocock sehingga didapatkan 14 orang. Selanjutnya ketika mengantisipasi drop out sampel kemudian ditambah 20\% sehingga sampel berjumlah 16 oerang per kelompok. Pada Kelompok 1 diberi pelalatihan reaching oblique crunch dan 
Kelompok 2 diberi pelatihan Pilate toe taps. Pelatihan dilakukan 3 kali dalam seminggu selama 6 minggu.

\section{B. Pengumpulan Data Penelitian}

Mengadakan koordinasi dengan kepala sekolah agar diberi ijin untuk meneliti di SMP Negeri 2 Kuta, kemudian meminta persetujuan kepada sampel dengan penjelasan secara lisan serta tulisan mengenai maksud dan tujuan penelitian dan hak yang diperoleh oleh sampel. Selanjutnya melaksanakan tes awal, tes awal diberikan saat sebelum di berikan pelatihan. Tes awal dilakukan 1 hari sebelum melakukan pelatihan. reaching oblique crunch dan pilate toe taps, dilakukan dengan diawali pemanasan 15 menit dan pendinginan selama 15 menit. Kemudian setelah 6 minggu melakukan tes akhir. Alat ukur untuk kekuatan otot perut adalah dengan melakukan test sit-up selama 30 detik. $^{8}$

\section{Analisis Data}

1. Uji Normalitas Data

Uji normalitas menggunakan shapiro-wilk test, dalam mengetahui sebaran data pada penelitian berdistribusi normal atau tidak. Data dengan pemaknaan berdistribusi normal jika nilai ( $>0,05)$, kemudian data berdistribusi tidak normal jika nilai $(\mathrm{p}<0,05)$.

\section{Uji Homogenitas}

Uji homogenitas dengan levene test, digunakan untuk mengetahui sebaran data apakah bersifat homogen atau tidak homogen. Data dikatakan homogen jika nilai $\mathrm{p}(\mathrm{p}>0,05)$, kemudian data tidak bersifat homogen jika nilai $\mathrm{p}(\mathrm{p}<0,05)$.

\section{Uji Hipotesis}

Uji yang digunakan untuk hipotesis 1 menggunakan uji Paired t-test menganalisis perbedaan efek pemberian reaching oblique crunch terhadap peningkatan kekuatan otot perut untuk menguji kemaknaan data sebelum dan sesudah pelatihan Kelompok 1. Uji hipotesis 2 menggunakan Paired t-test untuk mengetahui perbedaan efek pemberian pilate toe taps terhadap peningkatan kekuatan otot perut untuk menguji kemaknaan dari data sebelum dan sesudah pelatihan Kelompok 2. Uji hipotesis 3 menggunakan Independent t-test untuk mengetahui perbedaan pemberian reaching oblique crunch dan pilate toe taps terhadap peningkatan kekuatan otot perut dan untuk menguji kemaknaan pada kedua kelompok.

\section{HASIL PENELITIAN}

\section{A. Deskripsi Subjek Penelitian}

Tabel 1. Karakter subjek berdasarkan umur, berat badan dan tinggi badan.

\begin{tabular}{ccccccc}
\hline \multirow{2}{*}{$\begin{array}{c}\text { Karakteristik } \\
\text { Subjek }\end{array}$} & \multicolumn{2}{c}{ Kelompok 1 } & \multicolumn{4}{c}{ Kelompok 2 } \\
\cline { 2 - 7 } & $\mathbf{n}$ & Rerata & SB & N & Rerata & SB \\
\hline Umur (th) & 14 & 14,21 & 0,699 & 14 & 14,29 & 0,726 \\
$\begin{array}{c}\text { Berat Badan } \\
(\text { kg) }\end{array}$ & 14 & 54,5 & 3,344 & 14 & 55,2 & 3,148 \\
$\begin{array}{c}\text { Tinggi Badan } \\
(\mathbf{c m})\end{array}$ & 14 & 164,1 & 4,452 & 14 & 164 & 4,279 \\
\hline
\end{tabular}

Hasil analisis diperoleh nilai ( $p>0,05)$, sehingga hasil ini menunjukan bahwa setiap kelompok memiliki karakteristik fisik yang sama.

\section{B. Uji Normalitas dan Homogenitas}

Tabel 2. Hasil uji normalitas dan Homogenitas kekuatan otot perut kedua kelompok

\begin{tabular}{cccc}
\hline \multirow{2}{*}{$\begin{array}{c}\text { Kekuatan } \\
\text { Oto Perut }\end{array}$} & \multicolumn{2}{c}{ Uji Normalitas } & \\
\cline { 2 - 3 } & Kaphiro Wilk -Test) & Uji Normalitas \\
Kilai p & Klp 2 & Nilai p & $\begin{array}{c}\text { (Levene-Test) } \\
\text { Nilai p }\end{array}$ \\
\hline $\begin{array}{c}\text { Sebelum } \\
\text { Pelatihan }\end{array}$ & 0,646 & 0,325 & 0,918 \\
$\begin{array}{c}\text { Sesudah } \\
\text { Pelatihan }\end{array}$ & 1,000 & 0,602 & 0,378 \\
\hline
\end{tabular}

Data uji normalitas sebelum maupun sesudah pelatihan berdistribusi normal $(p>0,05)$ pada kedua kelompok sedangkan data uji homogenitas bersifat homogen $(p>0,05)$ baik data sebelum maupun sesudah pelatihan.

\section{Uji Beda Rerata Kekuatan Otot perut Sebelum Dan Sesudah Pelatihan}

Tabel 3. Hasil uji beda pelatihan sebelum dan sesudah pada ke dua kelompok

\begin{tabular}{cccccc}
\hline $\begin{array}{c}\text { PengukuranKekuatan otot } \\
\text { perut } \\
\text { (per 30 detik) }\end{array}$ & Rerata & SB & T & p \\
\hline Kelompok 1 & $\begin{array}{c}\text { Sebelum } \\
\text { Pelatihan } \\
\text { Sesudah } \\
\text { Kelatihan } \\
\text { Selompok 2 }\end{array}$ & 19,14 & 3,718 & 14,351 & 0,000 \\
$\begin{array}{c}\text { Sebelum } \\
\text { Pelatihan } \\
\text { Sesudah } \\
\text { Pelatihan }\end{array}$ & 18,07 & 20,28 & 3,221 & 10,333 & 0,000 \\
\hline
\end{tabular}

Hasil uji menunjukan uji beda reaching oblique crunch dan pilate toe taps pada Tabel 3 didapatkan hasil pengujian kedua kelompok menunjukan nilai $(\mathrm{p}>0,05)$ 


\section{Uji Beda Kekuatan Otot Perut Sebelum dan Sesudah Pelatihan}

Tabel 4. Hasil Uji Beda Pelatihan Sesudah dan Sebelum Dari ke dua Kelompok

\begin{tabular}{ccccc}
\hline & Kelompok & Rerata & T & P \\
\hline Sebelum & Kelompok 1 & $19,142 \pm 3,718$ & 0,815 & \\
pelatihan & Kelompok 2 & $18,071 \pm 3,221$ & 0,815 & \\
Sesudah & Kelompok 1 & $24,857 \pm 4,382$ & 3,051 & \\
pelatihan & Kelompok 2 & $20,285 \pm 3,495$ & 3,051 & 0,005 \\
\hline
\end{tabular}

Berdasarkan Tabel 4 bahwa didapatkan hasil analisis rerata dari kekuatan otot perut sebelum pelatihan baik Kelompok 1 dengan Kelompok 2 nilai $\mathrm{p}$ sebesar 0,426 hasil ini menunjukan $(p>0,05) \quad p$ lebih besar dari 0,05. Hal ni membuktikan tidak ada perbedaan bermakna hasil dari pre test baik Kelompok 1 dengan Kelompok 2 yang berarti bahwa kekuatan dari otot perut sebelum latihan pada kedua Kelompok komparabel. Beda rerata kekuatan otot setelah pelatihan antara Kelompok pelatihan Reaching Oblique Crunch dengan pelatihan Pilate Toe Taps didapatkan nilai p sebesar 0,005 atau p lebih kecil dari 0,05. Hal ni membuktikan ada perbedaan bermakna antara Kelompok 1 dengan Kelompok 2

\section{PEMBAHASAN}

\section{A. Peningkatan Kekuatan Otot Perut Setelah Pelatihan Reaching Oblique Crunch}

Dari uji yang terlihat menunjukan bahwa rerata data kekuatan otot perut sebelum dan sesudan pelatihan terdapat perbedaan yang bermakna $(p<0,05)$. Sebelum mendapat pelatihan 19,1 dan sesudan pelatihan 24,9 Sehingga dapat dikatakan pelatihan reaching oblique crunch dapat meningkatkan kekuatan otot perut. Latihan reaching oblique crunch merupakan latihan meraih miring dan meyilang gerakan ini dimulai dari posisi tidur dengan terletang dengan kedua tangan berada disebelah kiri dan kanan telinga kedua kaki di tekuk, latihan reaching oblique crunch merupakan jenis latihan tergolong murah dan mudah dilakukan dimanapun serta kapanpun, karena tidak memerlukan alat bantu. ${ }^{6}$

Latihan beban diperlukan untuk merapkan tata cara kondisi sistematis pada setiap kondisi otot tubuh meliputi otot Musculus Rectus Abdominis (bagian atas), Musculus Rectus Abdominis Medial (bagian tengah), Musculus Abdominis Inferior (bagian bawah) yang merupakan pembentuk otot sixpack (The Rectus abdominis), Musculus Oblique Abdominis yang merupakan kelompok otot perut yang berada disamping kira dan kanan Musculus rectus abdominis, Musculus oblique abdominis. Dari pengkondisian tersebut sangat efektif untuk meningkatkan ketahanan otot, pembentukan otot dan kekuatan otot dengan berat tubuh sendiri. ${ }^{10}$ Pada proses awal peningkatan kekuatan otot disebabkan dari perbaikan kontrol saraf motorik, koaktivasi otot antagonis dan agonis serta frekuensi motorik yang mengarah pada motor unit. Dapat terjadi perubahan dari struktur disebabkan dari proses latihan kekuatan, baik saat di serat otot atau di neuromuscular junction. ${ }^{11}$

\section{B. Peningkatan Kekuatan Otot Perut Setelah Pelatihan Pilate Toe Taps}

Dari hasil menunjukan bahwa rerata kekuatan dari otot perut pada saat sebelum pelatihan dan sesudah latihan terdapat perbedaan bermakna ( $p>0,05)$. Sebelum diberikan latihan 18,1 sesudah mendapat pelatihan 20,3 sehingga dapat dikatan pelatihan pilate toe taps dapat meningkatkan kekuatan otot perut. Pelatihan pilate toe taps merupakan pelatihan mengangkat jari-jari kaki dengan gerakan semula yaitu tidur dengan terlentang dengan kedua tangan lurus sebelah samping perut kemudian kaki posisi ditekuk 45 derajat. Gerakan pilate toe taps termasuk salah satu gerakan weight training yang mengembangkan dan meningkatkan kekuatan otot-otot perut seperti Rectus Abdominis bagian M. Rectus Abdominis Inferior (bagian bawah). M. Restus Abdominis Inferior, merupakan otot perut yang berada ditengah membentuk sixpack bagian otot yang berjumlah dua di bawah Musculus Rectus Abdominis Medial. $^{6}$

\section{Pelatihan reaching oblique crunch lebih meningkatkan kekuatan otot perut dari pada pelatihan pilate toe taps}

Dalam hasil menunjukan pelatihan reaching oblique crunch dan pilate toe taps kedua pelatihan tersebut dapat meningkatkan kekuatan otot perut. Untuk mendapatkan kemampuan fisik 
secara nyata maka harus melakukan pelatihan secara teratur, sistematis dan berkesinambungan. ${ }^{12}$ Bentuk pelatihan reaching oblique crunch dan pilate toe taps suatu metode yang cukup efektif dalam meningkatkan kekuatan dari otot perut serta pembentukan dari otot perut, otot berkontraksi secara kuat merupakan respon pembebanan secara dinamis, dari pembebanan tersebut terjadi hypertrophy otot yang mengakibatkan terjadinya peningkatan kekuatan otot perut. ${ }^{5}$ Pada otot yang hypertropy disebabkan meningkatkan ukuran besarnya serabut otot, terjadinya hypertropy otot dikarenakan akibat dari bertambahnya dari total myofibril dari setiap otot, dapat meningkatkan kepadatan (densitas) kapiler dari setiap serabut otot, bertambahnya jumlah serabut otot dan meningkatya jumlah protein. $^{13}$ Pelatihan reaching oblique crunch lebih meningkatkan kekuatan otot perut dikarenakan peningkatan pelatihan reaching oblique crunch lebih bermakana dari 19,1 menjadi 24,9 sedangkan pilate toe taps 18,1 menjadi 20,3. Pelatihan reaching oblique crunch lebih meningkatkan kekuatan otot perut dikarenakan lebih banyak mengenai bagian - bagian otot perut yakni meliputi otot bagian atas (Musculus rectus abdominis, bagian tengah (Musculus rectus abdominis medial), bagian bawah (Musculus abdominis inferior) yang merupakan pembentuk otot sixpack (The Rectus Abdominis), selain itu pelatihan Reaching Oblique Crunsh juga meningkatkan otot perut bagian Musculus Oblique Abdominis termasuk dalam otot perut yang posisinya di samping kiri dan samping kanan dari Musculus rectus abdominis, musculus oblique abdominis terdiri dari tiga bagian otot yaitu: M. External Oblique Abdominis, $M$. Internal Oblique Abdominis, M. Transverse Abdominis, sedangkan pelatihan pilate Toe Taps hanya meningkatkan otot perut bagian Rectus Abdominis bagian M. Rectus Abdominis Inferior (bagian bawah). ${ }^{6}$ Pelatihan reaching oblique crunch juga lebih meningkatkan kekuatan otot perut dimana pelatihan reaching oblique crunch lebih banyak melibatkan otot-otot tubuh bagian atas seperti: kepala, tangan, organ bagian dalam tubuh semua organ tersebut memiliki berat yang lebih dari tubuh bagian bawah. ${ }^{14}$ Gerakan yang mengangkat tubuh bagian atas lalu meraih dan menyilang memberikan beban yang lebih besar pada otot perut, dimana pelatihan Reaching oblique crunch beban pelatihan lebih berat dari pada pelatihan pilate toe taps yang hanya mengangkat tubuh bagian bawah (tungkai). Dimana beban yang lebih berat akan lebih meningkatkan kekuatan otot perut, dikarenakan prinsip dari beban berlebih, kekuatan otot akan lebih efektif jika diberikan beban sedikit diatas kemampuannya, hal ini berfungsi untuk mengadaptasikan fungsional tubuh, sehingga meningkatkan kekuatan otot perut. Latihan yang hanya menggunakan beban di bawah kemampuannya atau setara dengan kemampuannya, itu hanya akan dapat menjaga otot agar tetap setabil namun tidak meningkatkannya. Perinsip pembebanan (overload) menyatakan bahwa adaptasi peningkatan kekuatan otot yang mampu dicapai melalui latihan yang sistematik, frekuensi, progresif, intensitas yang dilakukan dalam durasi yang cukup untuk adaptasi. ${ }^{15}$ Maka dengan adanya prinsip beban lebih berat kelompok kelompok otot akan berkembang kekuatannya secara efektif. ${ }^{16}$ Pada dasarnya prinsip beban berlebih dapat menekan beban kerja yang dilakukan melebihi dari kemampuan yang dimiliki, sehingga harus mencapai ambang rangsang. Tujuannya adalah merangsang penyesuaian fisiologi tubuh sehingga dapat membantu peningkatan kemampuan kekuatan otot perut. ${ }^{17}$ Kekuatan otot perut merupakan komponen penting dalam peningkatan keseluruhan dari kondisi fisik, dikarenakan didasari oleh beberapa alasan: 1) kekuatan mempunyai peranan penting dalam melindungi seorang atlet dari kemungkinan terjadi cidera, 2) kekuatan adalah suatu penggerak dari sebuah aktivitas fisik, 3) melalui kekuatan maka seorang atlet mampu melempar, berlari, bahkan menendang lebih jauh serta memukul lebih keras, hal ini membantu kestabilan sendi - sendi. ${ }^{18}$

\section{SIMPULAN}

1. Pelatihan Reaching Oblique Crunch meningkatkan kekuatan otot perut siswa putra peserta ekstrakurikuler pencak silat SMP Negeri 2 Kuta.

2. Pelatihan Pilate Toe Taps meningkatkan kekuatan otot perut siswa putra peserta ekstrakurikuler pencak silat SMP Negeri 2 Kuta. 
3. Pelatihan Reaching Oblique Crunch lebih meningkatkan kekuatan otot perut dari pada pelatihan Pilate toe taps pada siswa putra peserta ekstrakurikuler pencak silat SMP Negeri 2 Kuta.

\section{SARAN}

1. Kepada para pelatih dan atlet khususnya pada cabang olahraga pencak silat bahwasanya pelatihan Reaching Oblique Crunch lebih baik dalam meningkatkan kekuatan otot perut.

2. Hasil dari penelitian ini diharapkan sebagai bahan efaluasi bagi pelatih serta atlet dalam mengevaluasi latihan dan sebagai penunjang penyusunan program latihan guna meningkatkan prestasi yang lebih baik, khususnya pada olahraga pencak silat.

3. Untuk peneliti berikutnya agar dijadikan sebuah refrensi ketika memilih permasalahan serupa pada penelitiannya.

\section{DAFTAR PUSTAKA}

1. Faruq, M. M. 2009. Sehat dan Cerdas Pendidikan Jasmani, Olahraga, dan Kesehatan. Grasindo, Jakarta

2. Anggraeni, J. 2016. Profil kondisi fisik Pencaksilat UNESA. Journal Fakultas Ilmu Keolahragaan, Universitas Negeri Surabaya.

3. Sukadiyanto. 2011. Pengantar Teoridan Metodologi Melatih Fisik. Bandung: Lubuk Agung

4. Nala, I. G. N. 2015. Prinsip Pelatihan Fisik Olahraga. Denpasar: Udayana University Press.

5. Trisnowijayanto, B. 2016. Pengaruh abdominal muscle strengthening dengan metode pilates. Jornal kesehatan volume VII, Nomer 3, Halaman 440-444

6. Laksono, B. A., dan Widyanto. 2016. Pengembangan Model Body Weight Training Untuk Latihan Otot Perut. Jurnal Ilmiah Kesehatan Olahraga, 15(2).

7. Makara, R. M. 2018. Perbandingan Efektivitas Antara Latihan Sit - Up dan Latihan Plank Terhadap Kekuatan Daya Tahan Otot Perut dan Penurunan Lingkaran Perut. Skripsi, Yogyakarta:FIK UNY.
8. Anwar, M.I. 2003. Dasar-Dasar Statistik, Bandung :Alfabeta.

9. Mackenzie, B. 2005. 101 Peformance Evaluation Test".London : Electric Word plc.

10. Maulana, S.L., Hadi S.S. 2015 Latihan Beban Lunge Dan Squter Squat Untuk Meningkatkan Kecepatan Renang Gaya Dada. Journal of Sport Sciences And Fitnes. 4(3).

11. Sudarsono, S 2011. Penyusun Program Pelatihan Beban Untuk Meningkatkan Kekuatan. Jurnal Ilmiah Sprint volume 11 Nomer 3, Halaman 31 - 43

12. Astrand, P. D., dan Rodahl, K . 2003. Texbook of Work Physiological Basic Of Exercise. Mc. Graw-Hill Book Company. HIm 47. New York

13. Sukadiyanto. 2011. Pengantar Teoridan Metodologi Melatih Fisik. Bandung: Lubuk Agung

14. Yosiati,N., Berlian.F Dan Yoni,N. 2012. Hubungan antara berat organ manusia Indonesia dengan umur, jenis Kelamin, panjang badan dan berat badan (Studi di RSUP Dr.Hasan Sandikin Bandung tahun 2008-2012). Journal Of Legal and Forensic Scinces 2012; 2(3):54-60

15. Griadhi,I.P.A.2019.Adaptasi Biomolekuler Hipertropi Jaringan Otot Rangka Pada Latihan Beban dan Manfaatnya Pada Sindroma Metabolik.Journal Sport and fitnes Voleme 7, No.2, Halaman 72-79

16. Chan, F. (2012). Strength training. Jurnal Cerdas Sifa. Edisi nomer 1, Mei -Agustus 2012. FKIP Universitas Jambi.

17. Bompa, T.O. 2000. Periodization, Theory and Methodelogy of Training 4th ed. Dubuque: $\quad$ kendal/Hunt Publisishing Company.

18. Dwikusworo, Ery Pratiknyo. 2010. Tes Pengukuran Dan Evaluasi Olahraga. Semarang: Widya Karya. 